\title{
ДОСВІД НМАПО ІМЕНІ П. Л. ШУПИКА ЩОДО ПІДВИЩЕННЯ КВАЛІФІКАЦІї ЗА ОЧНО-ЗАОЧНОЮ ФОРМОЮ 3 ЕЛЕМЕНТАМИ ДИСТАНЦЙНОГО НАВЧАННЯ У ФОРМАТІ ОН-ЛАЙН
}

\author{
Ю. В. Вороненко, Є. С. Латишев, В. М. Михальчук \\ Національна медична академія післядипломної освіти імені П. Л. Шупика

\section{EXPERIENCE OF NMAPGE BY P. L. SHUPYK OF TRAINING FOR PART-TIME FORM WITH ELEMENTS OF DISTANCE LEARNING FORMAT ONLINE}

\author{
Yu. V. Voronenko, Ye. Ye. Latyshev, V. M. Mykhalchuk \\ National Medical Academy of Postgraduate Education by P. L. Shupyk
}

\begin{abstract}
У статті висвітлено досвід НМАПО імені П. Л. Шупика щодо підвищення кваліфікації за очно-заочною формою 3 елементами дистанційного навчання у форматі он-лайн.
\end{abstract}

The article highlights the experience of NMAPGE by P. L. Shupyk of training for part-time form with elements of distance learning format online.

Вступ. Колектив нашої академії близько 10 років працює над запровадженням підвищення кваліфікації за очно-заочною формою з елементами дистанційного навчання (ДН) у форматі он-лайн, яке має свої переваги та відповідає попиту лікарів (провізорів).

Основна частина. Результати проведених соціологічних досліджень підтверджують бажання і готовність фахівців різних спеціальностей до запровадження таких форм підвищення кваліфікації.

Перший досвід був продемонстрований на прикладі спеціальностей "Організація і управління охороною здоров'я”, “Загальна практика-сімейна медицина”, "Кардіологія", "Нефрологія" з використанням друкованих інформаційних ресурсів та веб-ресурсів у форматі он-лайн.

Зазначений вид навчання дозволяє розширити можливість доступу лікарів до післядипломної освіти, зокрема підготовки на циклах ТУ та ПАЦ; збільшити кількість фахівців з одночасним зменшенням витрат на навчання, проїзд і проживання; індивідуалізувати процес навчання відповідно до потреб, особливостей і можливостей слухачів; забезпечити контроль якості післядипломного навчання; формувати передумови для опанування слухачами навичок самостійної роботи. Така підготовка проводиться у межах навчального плану закладу та позапланово на договірній основі.

( Ю. В. Вороненко, С. С. Латишев, В. М. Михальчук
Підгрунтям для такого виду підвищення кваліфікації стали накази Міністерства освіти і науки України № 466 від 25. 04.2013 р. "Про затвердження Положення про дистанційне навчання", зареєстрований у Міністерстві юстиції України 30.04.2013 р. за № 703/ 23235 та № 1518 від 30.10.2013 р. "Про затвердження Вимог до вищих навчальних закладів та закладів післядипломної освіти, наукових, освітньо-наукових установ, що надають освітні послуги за дистанційною формою навчання з підготовки та підвищення кваліфікації фахівців за акредитованими напрямами i спеціальностями", зареєстрований у Міністерстві юстиції України 31 жовтня 2013 р. за № 1857/24389.

Доробком фахівців академії у сфері післядипломної медичної освіти стали Примірне положення про підвищення кваліфікації за очно-заочною формою 3 елементами дистанційного навчання у Національній медичній академії післядипломної освіти імені П. Л. Шупика, яке погоджене на спільному засіданні Координаційної науково-методичної ради з післядипломної освіти та Робочої групи щодо реформування післядипломної освіти МОЗ України 30 травня 2013 року, й ряд затверджених на вченій раді навчальних планів та програм циклів ТУ за такою формою підготовки.

Останнім системним кроком на шляху розвитку зазначеного виду навчання було обговорення 10 квітня 2014 року на спільному засіданні Координаційної науково-методичної ради з післядипломної освіти 
та Робочої групи щодо реформування післядипломної освіти, погодження МОЗ України та затвердження вченою радою академії Навчального плану та уніфікованої програми передатестаційного циклу за спеціальністю “Організація іуправління охороноюздоров'я" (за очно-заочною формою з елементами дистанційного навчання), яка передбачає до 50 відсотків навчального матеріалу засвоювати в форматі он-лайн, відкриваючи нові можливості для підвищення кваліфікації лікарів (провізорів) всієї України, та методичних рекомендацій “'Організація підвищення кваліфікації за очно-заочною формою з елементами дистанційного навчання у форматі он-лайн (досвід Національної медичної академії післядипломної освіти імені П. Л.Шупика)", що розтлумачують організаційні засади проведення такого виду навчання.

Особливостями такого виду навчання $є$ норматив чисельності слухачів, що навчаються у навчальному закладі за дистанційною формою, який повинен становити не менше одного викладача на вісімнадцять слухачів; педагогічні, науково-педагогічні працівники та методисти навчальних закладів, в яких організована дистанційна форма навчання, повинні підвищувати свою кваліфікацію щодо організації та володіння технологіями ДН (не рідше одного разу на 5 років та обсягом не менше 108 академічних годин) із підтвердженням документом про підвищення кваліфікації за тематикою ДН; лекційний матеріал у текстовому вигляді з графіками, малюнками та таблицями повинен бути не менше 10000 знаків (1/4 друкованого аркуша) на 1 академічну годину та не менше 20 тестових завдань для усіх видів контролю рівня знань (самоконтроль, поточний і підсумковий контроль) до кожної теми.

Крім того, фахівцями академії обгрунтовані рекомендовані проектні нормативи часу для обліку методичної та навчальної роботи науково-педагогічних працівників при організації і здійсненні навчального процесу за дистанційною формою навчання стосовно методичної та навчальної роботи й наступне співвідношення аудиторно/дистанційних годин: для клінічних дисциплін - 60/40 відсотків академічних годин; для теоретичних дисциплін - 50/50 відсотків академічних годин. Обгрунтована методика розрахунку педагогічного навантаження науково-педагогічних працівників на прикладі передатестаційного циклу або тематичного удосконалення тривалістю 156 годин.

Перший етап (підвищення кваліфікації з елементами ДН) передбачає навчання з використанням вебресурсів навчального призначення, взаємодією між викладачами і слухачами у синхронному та асинхронному режимах.

Другий етап (очне навчання) передбачає навчання на кафедрі, співбесіду (контроль знань) та оформлення необхідних документів щодо результатів закінчення навчання.

Висновок. Навчання за такою формою керівників медичних установ - це свідомий крок на шляху широкого впровадження зазначеної форми навчання, тому що саме організатори охорони здоров'я першими мають пройти такий вид навчання та розповсюджувати його серед інших лікарів. 